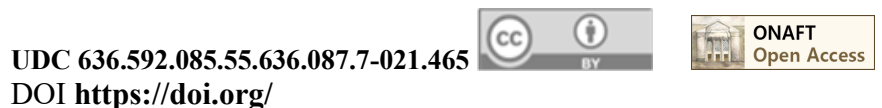

B. Iegorov, Doctor of Science, Professor, E-mail: bogdanegoroff58@gmail.com ORCID 0000-0001-7526-0315, ResearcherID: Q-1365-2015

Scopus Author ID: 56578802600

A. Makarynska, PhD. Sc., Ass. Professor, E-mail: allavm2015@gmail.com ORCID: 0000-0003-1879-8455, Researcher ID: C-5217-2016,

Scopus ID: 57192819060

N. Vorona, PhD. Sc., Ass. Professor, E-mail: tarnin@te.net.ua ORCID 0000-0001-6903-9016, Researcher ID: F-8020-2016

Scopus ID: 57188205800

Department of Technology of Mixed Feeds and Biofuel Odessa National Academy of Food Technologies, 112, Kanatna Str., 65039, Odessa, Ukraine, +38487124113

\title{
QUALITY EVALUATION OF PROTEIN FEED ADDITIVE AND TURKEY COMPOUND FEED
}

\begin{abstract}
The article describes that there is a problem of providing the population of the planet with a complete protein in the world today. It is proved that its lack can lead to significant pathologies. This issue becomes very acute with the rapid increase in the number of people on Earth. In this situation the challenge is complicated for compound feed producers because it is necessary to provide protein feeds to farm animals and poultry to meet people's needs for animal protein products. However, feed manufacturers should not use protein raw materials that can be consumed as food.

Based on cooperation with compound feed producers, the task of finding alternative sources of protein raw materials, preferably of vegetable origin, is set.

The optimal composition of protein feed additive (PFA) for soybean meal replacement in compound feeds for farm animals and poultry has been developed. PFA can be manufactured at a feed mill with portion technology by weighing portions of components and mixing in a paddle periodic action mixer. PFA can be used as a part of compound feeds for poultry farms and livestock complexes, feed concentrates for poultry and livestock farms, feed mills with advanced technology, inter-farm or mini-feed mills.

We have developed compound feed recipes for heavy type turkeys using PFA to determine the cost-effectiveness of using PFA in compound feed. Turkeys have been chosen as a poultry because they are the most demanding birds to the quality and quantity of protein in the ration.

The experimental samples of PFA were made in accordance with the developed recipes. We determined their physical properties and chemical composition. The PFA experimental samples match the quality of soybean meal according to the physical properties and chemical composition.

In accordance with the developed recipes of mixed feeds for heavy type turkeys experimental samples of starter and grower feeds were made. Research of the physical properties and chemical composition of compound feeds has shown that the replacement of soybean meal with PFA in their composition does not affect the nutritional value and technological properties of the final product.

Key words: compound feed for turkeys, physical properties, chemical composition, protein feed additive, soybean meal, nutritional indicators.
\end{abstract}

\section{Introduction}

In the world today there is a problem of providing the population of the planet with a complete protein. It is a structural material for the human body and its lack can lead to significant pathologies. This issue becomes very acute with the rapid increase in the number of people on Earth [1]. In this situation the challenge is complicated for compound feed producers because it is necessary to provide protein feeds to farm animals and poultry to meet people's needs for animal protein products. However, feed manufacturers should not use protein raw materials that can be consumed as food.

Thus, compound feed producers face the urgent task of finding alternative sources of protein raw materials, preferably of vegetable origin.

Soybean meal is considered to be the ideal protein raw material of plant origin in compound feed recipes. Its market price is $13500-13800 \mathrm{UAH} / \mathrm{t}[2,3]$.

We have developed the optimal composition of protein feed additive (PFA) for soybean meal replacement in compound feeds for farm animals and poultry. PFA can be manufactured at a feed mill with portion technology by weighing portions of components and mixing in a paddle periodic action mixer. PFA can be used as a part of compound feeds for poultry farms and livestock complexes, feed concentrates for poultry and livestock farms, feed mills with advanced technology, inter-farm or mini-feed mills [4].

We have developed compound feed recipes for heavy type turkeys using PFA to determine the costeffectiveness of using PFA in compound feed. Turkeys have been chosen as a poultry because they are the most demanding birds to the quality and quantity of protein in the ration. The need for turkeys on the starting period in crude protein is $28 \%$ [5-9]

\section{Purpose and objectives of the analysis}

The purpose of the research is to study the physical properties and chemical composition of the experimental samples of protein feed additive in comparison with soybean meal and compound feed for heavy type turkeys, which included PFA or soybean meal. Standard methods of analysis were used for the research. 


\section{Results and its discussion}

In order to reduce the cost of mixed feed, we have proposed the optimal composition of protein feed additive to replace an expensive soybean meal in feed recipes. We have developed 7 PFA recipes of various composition using the "Korm Optima Expert" software complex (table 1) [10,11].

At the department of technology of mixed feeds and biofuel at Odessa National Academy of Food Technologies the experimental samples of PFA were made in accordance with the developed recipes (samples № 5, 6, 7). We determined their physical properties and chemical composition.

The experimental samples of PFA were analyzed by the indicators that most characterize the techno- logical properties of the finished product. They are the angle of repose, flowability, bulk density and moisture content. In the table 2 the results of the study of the physical properties of PFA samples № 5, 6, 7 and soybean meal are presented.

Data analysis in table 2 indicates that moisture content of PFA experimental samples is lower by $2 \%$ than soybean meal. The bulk density and the angle of repose of the experimental samples are lower, and the flowability is better than soybean meal.

PFA nutritional value was evaluated by the content of dry matter, crude protein, crude fat, crude fiber, crude ash, macronutrients, and amino acids.

Table 1 - Composition, nutritional value and cost of $P F A$ recipes

\begin{tabular}{|c|c|c|c|c|c|c|c|}
\hline Components and nutrients & $\begin{array}{c}\text { Sample } \\
\text { №1 }\end{array}$ & $\begin{array}{c}\text { Sample } \\
\text { №2 }\end{array}$ & $\begin{array}{c}\text { Sample } \\
\text { №3 }\end{array}$ & $\begin{array}{c}\text { Sample } \\
\text { №4 }\end{array}$ & $\begin{array}{c}\text { Sample } \\
\text { №5 }\end{array}$ & $\begin{array}{c}\text { Sample } \\
\text { №6 }\end{array}$ & $\begin{array}{c}\text { Sample } \\
\text { №7 }\end{array}$ \\
\hline Wheat bran & - & - & - & - & - & 2,00 & - \\
\hline Wheat fodder flour & - & - & - & - & 2,00 & - & 2,00 \\
\hline Sunflower meal, CP $40 \%$ & 92,30 & 91,80 & 89,70 & 88,00 & 85,10 & 83,00 & 80,00 \\
\hline Sunflower oil & 2,00 & 1,90 & 2,00 & 1,70 & 1,1 & 1,20 & 1,20 \\
\hline Fodder yeast, CP $44 \%$ & 3,00 & 4,00 & 6,00 & 8,00 & 10,00 & 12,00 & 15,00 \\
\hline Lysine monochlorhydrate $98 \%$ & 1,50 & 1,32 & 1,30 & 1,24 & 1,21 & 1,16 & 1,10 \\
\hline L-threonine $98 \%$ & 0,30 & 0,30 & 0,25 & 0,16 & 0,15 & 0,15 & 0,11 \\
\hline $\mathrm{L}-$ tryptophan, $98 \%$ & 0,20 & 0,18 & 0,10 & 0,04 & 0,04 & 0,04 & 0,04 \\
\hline Limestone flour & 0,70 & 0,50 & 0,65 & 0,86 & 0,40 & 0,45 & 0,55 \\
\hline Total & 100 & 100 & 100 & 100 & 100 & 100 & 100 \\
\hline The cost of PFA, UAH/t & 11232 & 11036 & 10889 & 10637 & 10487 & 10442 & 10329 \\
\hline Gross energy, $\mathrm{MJ} / \mathrm{kg}$ & 17,82 & 17,88 & 17,91 & 17,85 & 17,80 & 17,82 & 17,84 \\
\hline \multicolumn{8}{|l|}{ Mass fraction, $\%$ : } \\
\hline crude protein & 40,03 & 40,09 & 40,01 & 40,04 & 40,00 & 40,00 & 40,03 \\
\hline crude fat & 3,61 & 3,52 & 3,61 & 3,31 & 2,75 & 2,87 & 2,84 \\
\hline c18:2 $\omega 6$ & 2,01 & 1,94 & 1,99 & 1,79 & 1,41 & 1,47 & 1,43 \\
\hline crude fiber & 14,81 & 14,74 & 14,44 & 14,19 & 13,84 & 13,64 & 13,09 \\
\hline crude ash & 7,48 & 7,29 & 7,37 & 7,54 & 7,01 & 7,04 & 7,00 \\
\hline lysine & 2,54 & 2,42 & 2,43 & 2,42 & 2,43 & 2,42 & 2,42 \\
\hline methionine & 0,83 & 0,83 & 0,82 & 0,81 & 0,80 & 0,79 & 0,77 \\
\hline methionine + cystine & 1,42 & 1,42 & 1,40 & 1,40 & 1,38 & 1,36 & 1,34 \\
\hline threonine & 1,67 & 1,68 & 1,65 & 1,58 & 1,58 & 1,59 & 1,58 \\
\hline tryptophan & 0,70 & 0,69 & 0,61 & 0,55 & 0,55 & 0,55 & 0,55 \\
\hline calcium & 0,60 & 0,53 & 0,59 & 0,67 & 0,50 & 0,53 & 0,57 \\
\hline phosphorus & 1,06 & 1,07 & 1,07 & 1,08 & 1,08 & 1,10 & 1,10 \\
\hline phosphorus available & 0,31 & 0,33 & 0,34 & 0,36 & 0,38 & 0,41 & 0,43 \\
\hline sodium & 0,08 & 0,08 & 0,08 & 0,08 & 0,08 & 0,09 & 0,09 \\
\hline chlorine & 0,36 & 0,32 & 0,32 & 0,31 & 0,30 & 0,29 & 0,28 \\
\hline
\end{tabular}


In the table 3 the chemical composition of the PFA according to the developed recipes of samples № 5, 6, 7 and soybean meal are presented. Data analysis shows that the crude fat content in the PFA is higher than in the soybean meal due to the additional introduction of sunflower oil. The increased content of crude fiber, methionine + cystine and phosphorus in PFA is associated with more of these substances in the composition of sunflower meal and fodder yeast than in soybean meal. The excess calcium in PFA is explained by the introduction of limestone flour into its composition.

In accordance with the developed recipes of mixed feeds for heavy type turkeys [3] experimental samples of starter and grower feeds were made. Soybean meal was included in the starter feed № 1 and the grower feed № 3, and soybean meal was replaced with PFA in the starter feed № 2 and the grower feed № 4. The physical properties and chemical composition were determined in the experimental samples of starter and grower feeds.

The compound feeds were examined for the following indicators: the angle of repose, flowability, bulk density and moisture content. The results of the studies are given in the table 4.

As can be seen from the obtained data, the replacement in the recipe of compound feed for young heavy type turkeys of soybean meal on PFA does not significantly affect the physical properties of compound feeds. Thus, the experimental samples of starter and grower feeds are characterized by satisfactory physical properties.

Feed value of compound feeds, which were made according to the developed recipes, was estimated on the basis of the nomenclature of guaranteed quality indicators of compound feed, taking into account the detailed feeding norms of young turkeys by the following indicators: crude protein, crude fat, crude fiber, crude ash, calcium, phosphorus, lysine, methionine + cystine, threonine, tryptophan.

The data of chemical and amino acid composition of compound feeds for young turkeys are presented in the table 5 .

Table 2 - The physical properties of PFA samples and soybean meal

\begin{tabular}{|c|c|c|c|c|}
\hline \multirow{2}{*}{ Indicators } & \multirow{2}{*}{$\begin{array}{c}\text { Soybean } \\
\text { meal }\end{array}$} & \multicolumn{3}{|c|}{ PFA } \\
\hline & & Sample № 5 & Sample № 6 & Sample № 7 \\
\hline Moisture content, $\%$ & 1010,0 & 9,0 & 9,0 & 9,0 \\
\hline The angle of repose, degree & 48,0 & 44,0 & 44,0 & 44,0 \\
\hline Flowability, $\mathrm{cm} / \mathrm{s}$ & 30,6 & 32,4 & 32,8 & 33,1 \\
\hline Bulk density, $\mathrm{kg} / \mathrm{m}^{3}$ & 540,0 & 522,0 & 516,0 & 521,0 \\
\hline
\end{tabular}

Table 3 - Chemical and amino acid composition of PFA and soybean meal (based on dry matter)

\begin{tabular}{|c|c|c|c|c|}
\hline \multirow{2}{*}{ Nutrients } & \multirow{2}{*}{$\begin{array}{c}\text { Soybean } \\
\text { meal }\end{array}$} & \multicolumn{3}{|c|}{ PFA } \\
\hline & & Sample № 5 & Sample № 6 & Sample № 7 \\
\hline Dry matter, $\%$ & 90,00 & 91,00 & 91,00 & 91,00 \\
\hline Crude protein, $\%$ & 44,4 & 43,96 & 43,96 & 43,99 \\
\hline Crude fat, $\%$ & 1,33 & 3,02 & 3,15 & 3,12 \\
\hline Crude fiber, $\%$ & 11,78 & 15,21 & 14,99 & 14,38 \\
\hline Crude ash, $\%$ & 7,78 & 7,70 & 7,74 & 7,69 \\
\hline Calcium, $\%$ & 0,41 & 0,55 & 0,58 & 0,63 \\
\hline Phosphorus, \% & 0,72 & 1,19 & 1,21 & 1,21 \\
\hline Lysine, $\%$ & 2,69 & 2,67 & 2,66 & 2,66 \\
\hline Methionine + cystine, $\%$ & 1,22 & 1,52 & 1,49 & 1,47 \\
\hline Threonine, $\%$ & 1,76 & 1,74 & 1,75 & 1,74 \\
\hline Tryptophan,\% & 0,61 & 0,60 & 0,60 & 0,60 \\
\hline
\end{tabular}

Table 4 - The physical properties of turkey compound feed

\begin{tabular}{|c|c|c|c|c|}
\hline Indicators & $\begin{array}{c}\text { Compound feed } \\
\text { №1 } \\
\end{array}$ & $\begin{array}{c}\text { Compound feed } \\
\text { №2 } \\
\end{array}$ & $\begin{array}{c}\text { Compound feed } \\
\text { №3 } \\
\end{array}$ & $\begin{array}{c}\text { Compound feed } \\
\text { №4 } \\
\end{array}$ \\
\hline Moisture content, $\%$ & 12,0 & 11,7 & 12,1 & 11,5 \\
\hline The angle of repose, degree & 40,0 & 38,5 & 441,0 & 38,0 \\
\hline Flowability, cm/s & 6,8 & 7,0 & 6,5 & 7,4 \\
\hline Bulk density, $\mathrm{kg} / \mathrm{m}^{3}$ & 515,0 & "513,0 & 516,0 & $\overline{512,0}$ \\
\hline
\end{tabular}


Table 5 - Chemical and amino acid composition of compound feeds for young heavy type turkeys (based on dry matter)

\begin{tabular}{|c|c|c|c|c|}
\hline Nutrients & $\begin{array}{c}\text { Compound feed } \\
\text { №1 }\end{array}$ & $\begin{array}{c}\text { Compound feed } \\
\text { №2 }\end{array}$ & $\begin{array}{c}\text { Compound feed } \\
\text { №3 }\end{array}$ & $\begin{array}{c}\text { Compound feed } \\
\text { №4 }\end{array}$ \\
\hline Dry matter, $\%$ & 88,00 & $\begin{array}{r}88,30 \\
\end{array}$ & 87,90 & 88,50 \\
\hline Crude protein, $\%$ & 31,80 & 31,70 & 24,98 & 25,15 \\
\hline Crude fat, $\%$ & $9,9,03$ & 9,16 & 10,53 & 10,46 \\
\hline Crude fiber, $\%$ & 4,13 & 4,36 & 5,33 & 5,14 \\
\hline Crude ash, $\%$ & 8,98 & 8,95 & 8,49 & 8,56 \\
\hline Calcium, $\%$ & 1,94 & 1,95 & 2,00 & 2,00 \\
\hline Phosphorus, \% & 1,14 & 1,18 & 0,98 & 0,94 \\
\hline Lysine, $\%$ & 1,78 & 1,79 & 1,34 & 1,35 \\
\hline Methionine + cystine, $\%$ & 1,14 & 1,16 & 0,92 & 0,90 \\
\hline Threonine, $\%$ & 1,17 & 1,16 & 0,90 & 0,91 \\
\hline Tryptophan,\% & 0,35 & 0,35 & 0,25 & 0,25 \\
\hline
\end{tabular}

The data analysis of the table 5 indicates that the replacement of soybean meal by PFA in the compound feed for turkeys does not affect their nutritional value. The produced compound feeds are balanced in content of nutrients and biologically active substances and meet the physiological needs and feeding standards of heavy type turkeys.

\section{Conclusions}

We have developed recipes of PFA and compound feeds for heavy type turkeys with the help of the software complex "Korm Optima Expert". The PFA is designed to replace soybean meal in compound feed recipes. The PFA is cheaper than soybean meal. The PFA experimental samples match the quality of soybean meal according to the physical properties and chemical composition.

Soybean meal was replaced by PFA in recipes of compound feeds experimental samples for heavy type turkeys № 2 and № 4. Research of the physical properties and chemical composition of compound feeds has shown that the replacement of soybean meal with PFA in their composition does not affect the nutritional value and technological properties of the final product.

\section{REFERENCES}

1. Yehorov B.V. Tekhnolohiya virobnitstva kombikormiv: pidruchnik. Odesa: Drukars 'kiy dim, 2011. - 448 s.

2. Soyeviy shrot // Pidpriyemstvo po pererobtsi soyi: [Veb-sayt]. Odesa, 2019. URL: http://soybean.com.ua/ua/soybean-fodder (data zvernennya: 07.10.2019).

3. Soevyy shrot // Vikipediya-svobodnaya entsiklopediya: [Veb-sayt]. Odesa, 2019. URL: https://ru.wikipedia.org/wiki/Soevyy_shrot (data zvernennya:06.10.2019).

4. Dersjant-Li Yueming, Peisker Manfred. Application of soy protein concentrate in poultry pre-starter feed // Allaboutfeed, 2010. Sep. [Веб-caüm]. https://www.allaboutfeed.net/Nutrition/DietFormulation/2010/9/Application-of-soy-protein-concentrate-in-poultry-pre-starter-feed-AAF011676W/

5. Makarinska A.V., Vorona N.V.Obtruntuvannya viboru sirovini dlya virobnitstva bilkovoyi kormovoyi dobavki // Scientific Works. / Odes. nats. akad. kharch. tekhnolohiy. Odesa, 2019. T. 83, vip. 2. S. 26-32.

6. Makarynska, A. Optimization of feed composition for turkeys / A. Makarynska, N. Vorona // Grain Products and Mixed Fodder's. - 2019. - Vol. 19, Issue 4 (76). - P. 46-50.

7. Chernyshev N. I., Panin I. H. Komponenty kombikormov. Voronezh: HUP VO «Voronezhskaya oblastnaya tipohrafiya», 2012. $154 \mathrm{~s}$.

8. Davies J. Turkey feed: Structure affects performance // Allaboutfeed, 2019. Apr. [Veb-sayt]. https://www.allaboutfeed.net/Compound-Feed/Articles/2019/4/Turkey-feed-Structure-affects-performance419279E/

9. Caldier P. Challenges in išpiturkey breeding // Allaboutfeed, 2014. Apr. [Veb-sayt]. https://www.allaboutfeed.net/Raw-Materials/Articles/2014/4/Challenges-in-turkey-breeding-1440963W/

10. Akinde O. Enhancing poultry performance with nutritional supplements // Poultry World, 2012. Nov. [Vebsayt]. https://www.poultryworld.net/Home/General/2012/11/Enhancing-poultry-performance-with-nutritionalsupplements-1107871W/

11. Software complex "Korm Optima Expert”, 2006. 
Б.В. Сгоров, д-р техн. наук, професор, E-mail: bogdanegoroff58@gmail.com

А.В. Макаринська, канд. техн. наук, доцент, E-mail: allavm2015@gmail.com

Н.В. Ворона, канд. техн. наук, доцент, E-mail: tarnin@te.net.ua Кафедра технології комбікормів і біопалива,

Одеська національна академія харчових технологій, ул. Канатная, 112, м. Одеса, 65039, Украӥна

\title{
ОЦІНКА ЯКОСТІ БІЛКОВОЇ КОРМОВОЇ ДОБАВКИ ТА КОМБІКОРМІВ ДЛЯ ІНДИКІВ
}

\begin{abstract}
Анотація
У статті зазначено, що съогодні існує проблема забезпечення населення планети повноцінним білком. Доведено, щз його відсутність може призвести до значних патологій. Це питання стає дуже гостро із швидким збільшенням кількості людей на Землі. У иіій ситуації проблема ускладнюється для виробників комбікормів, оскільки для забезпечення потреб людей у білкових продуктах тваринного походження необхідно забезпечувати білковими кормами сільськогосподарських тварин та птицю. Однак виробники кормів не повинні використовувати білкову сировину, яка може бути використана для харчових иілей. На основі співпраці з виробниками комбікормів постало питання пошуку альтернативних джерел білковоі сировини, бажано рослинного походження.

Розроблено оптимальний склад білкової кормової добавки (БКД) для заміни соєвого шроту в комбікормах для сільськогосподарських тварин та птиці. БКД можна виготовляти на комбікормовому заводі за пориійною технологією шиляхом зважування пориій компонентів та перемішування в лопатевому змішувачі періодичної дії. БКД може використовуватися у складі комбікормів для птахофабрик та тваринницьких комплексів, кормових концентратів для птахівницьких та тваринницьких ферм, комбікормових заводів з передовою технологією, міжгосподарських або міні-комбікормових заводів.

Розроблено рецепти комбікормів для індиків важкого типу з використанням БКД, щоб визначити економічну ефективність використання БКД в комбікормах. Індичок було вибрано як домашню птицю, оскільки вони є найбільш вимогливими птахами до якості та кількості білка в рачіоні.

Експериментальні зразки БКД були виготовлені відповідно до розроблених рецептур. Ми визначили їх фізичні властивості та хімічний склад. Експериментальні зразки БКД відповідають якості соєвого шроту за фізичними властивостями та хімічним складом.

Відповідно до розроблених рецептур комбікормів для індиків важккого типу були виготовлені експериментальні зразки стартових та гроуерних комбікормів. Дослідження фізичних властивостей та хімічного складу комбікормів показало, щзо заміна соєвого шроту на БКД у їх складі не впливає на кормову иінність та технологічні властивості кінцевого продукту.
\end{abstract}

Ключові слова: комбікорми для індиків, фізичні властивості, хімічний склад, білкова кормова добавка, соєвий шрот, показники поживної цінності.

\section{ЛІТЕРАТУР}

1. Сгоров Б. В. Технологія виробництва комбікормів: підручник. Одеса: Друкарський дім, 2011. - 448 с.

2. Соєвий шрот // Підприсмство по переробиі сої: [Веб-сайт]. Одеса, 2019. Режим доступу: URL: http://soybean.com.ua/ua/soybean-fodder (дата звернення: 07.10.2019).

3. Соєвий шрот // Вікіпедія - вільна енциклопедія: [Веб-сайт]. Одеса, 2019. Режим доступу: URL: https://ru.wikipedia.org/wiki/Soevyy_shrot ((дата звернення: 06.10.2019).

4. Dersjant-Li Yueming, Peisker Manfred. Application of soy protein concentrate in poultry pre-starter feed // Allaboutfeed, 2010. Sер. [Веб-сайт]. Режим доступy: https://www.allaboutfeed.net/Nutrition/Diet-Formulation/2010/9/Applicationof-soy-protein-concentrate-in-poultry-pre-starter-feed-AAF011676W/

5. Макаринська А.В. Обтрунтування вибору сировини для виробництва білкової кормової добавки / А.В. Макаринська, Н.В. Ворона // Наукові прачі / ОНАХT. - Одеса, 2019. - T. 83, Bun. 2. C. $26-32$.

6. Makarynska, A. Optimization of feed composition for turkeys / A. Makarynska, N. Vorona // Grain Products and Mixed Fodder's. - 2019. - Vol. 19, Issue 4 (76). - P. 46-50.

7. Чернышев Н.И., Панин И.Н. Компоненты комбикормов. Воронеж: ХУП ВО «Воронежская областная типография», 2012. -154 c.

8. Davies J. Turkey feed: Structure affects performance // Allaboutfeed, 2019. Apr. [Веб-сайm]. Режим доступy: https://www.allaboutfeed.net/Compound-Feed/Articles/2019/4/Turkey-feed-Structure-affects-performance-419279E/

9. Caldier P. Challenges in isepiturkey breeding // Allaboutfeed, 2014. Apr. [Веб-сайm]. Режим достуny: https://www.allaboutfeed.net/Raw-Materials/Articles/2014/4/Challenges-in-turkey-breeding-1440963W/

10. Akinde O. Enhancing poultry performance with nutritional supplements // Poultry World, 2012. Nov. [Веб-сайm]. Режим docmyny: $\quad$ https://www.poultryworld.net/Home/General/2012/11/Enhancing-poultry-performance-with-nutritionalsupplements-1107871W/

11. Програмний комплекс «Корм Оптіма Експерт», 2006.

Received 24.06.2020

Reviewed 07.07.2020

Cite as Vancouver Citation Style

Iegorov B., Makarynska A., Vorona N. Quality evaluation of protein feed additive and turkey compound feed. Grain Products and Mixed Fodder's, 2020; 20 (3, 79): 34-38. DOI https://doi.org/

Cite as State Standard of Ukraine 8302:2015

Quality evaluation of protein feed additive and turkey compound feed / Iegorov B. et al. // Grain Products and Mixed Fodder's.

2020. Vol. 20, Issue 3 (79). P. 34-38. DOI https://doi.org/

*

Revised $\quad 30.07 .2020$ Approved 28.08.2020 